\title{
DAMPAK DARI WABAH CORONA VIRUS DISEASE-19
}

\author{
Erina Dewi Rianti, Muhammad ali sodik \\ IIK Strada Indonesia \\ erynadewy@gmail.com, alisodik2012@gmail.com
}

\begin{abstract}
ABSTRAK
Corona Virus atau COVID-19 yang sudah dinyatakan sebagai pandemi karena sudah meluas diseluruh negara. Indonesia adalah salah satu negara yang tertular COVID-19 dan saat ini perekonomian di Indonesia pun sedang mengalami penurunan karena banyak usaha-usaha yang tutup karena sepinya pengunjung dan pekerja yang mengalami PHK karena pemiliki usaha tidak mampu menggaji. Pandemi ini tidak hanya menimbulkan masalah ekonomi saja akan tetapi masalah social juga karena dengan adanya COVID-19 tingkat mortalitas atau kematian semakin meningkat tiap hari nya dan masyarakat diberi batasan untuk melakukan sosialisasi guna mencegah menyebarnya COVID-19. Lansia merupakan suatu kelompok penduduk yang cukup rentan dan terdampak dalam masalah kesehatan danpsikologis di era pandemi COVID 19 (new normal). Salah satu usaha dari pemerintah dalam menjaga lansiaagar tidak terpapar wabah ini adalah dengan promosi kesehatan di Posyandu Lansia.
\end{abstract}

\section{Latar Belakang}

Baru-baru ini Indonesia digemparkan dengan berita menyebarnya sebuah virus yang berasal dari China. Virus yang berasal dari China ini dikenal dengan nama Coronavirus. Coronavirus merupakan salah satu virus yang serupa dengan common cold atau pilek yang dapat menyebabkan penyakit ringan hingga serius. Virus ini merupakan virus yang berasal dari hewan seperti kelelawar yang ditularkan kemanusia di Kota Wuhan, China. Virus ini pun akhirnya menyebar hingga seluruh dunia bahkan indonesia. World Health Organization (WHO) telah menetapkan bahwa Covid-19 atau coronavirus ini merupakan pandemi yang sampai menyebar ke seluruh penjuru dunia dan menyebabkan banyak permasalahan sosial, ekonomi dan menyebabkan kenaikan mortalitas (kematian) pada masyarakat. Pemerintah pun berupaya semaksimal mungkin agar bisa menangani pasien-pasien Covid-19 dengan baik dan juga memberikan alat pencegahan kepada kalangan bawah. Selain itu kondisi saat ini dimana Indonesia sebagai negara yang memiliki bonus demografi yang seharusnya sedang dalam kondisi membangun sebuah kekuatan ekonomi yang sangat besar harus mengalami keterlambatan ekonomi akibat dari wabah virus ini dimana kondisi saat ini membuat perekonomian negara menjadi terganggu. Selain itu adanya program PSBB serta progran Physical Distancing diberbagai daerah sebagai langkah negara dalam mencegah penularan virus tersebut ternyata memiliki dampak yang buruk dalam segi pertumbuhan ekonomi. Banyaknya yang mengalami pemutusan hubungan kerja ini membuat tingginya jumlah angka pengangguran. Hal ini lah yang menjadi ancaman bagi ekonomi di Negara Indonesia. Pemberian bantuan dari Pemerintah Daerah 
kepada individu, keluarga, kelompok dan/atau masyarakat. Sifat bantuan ini, tidak secara terus dan selektif. Bantuan ini berupa uang atau barang yang pemberiannya disesuaikan dengan kemampuan keuangan daerah. Tujuannya untuk menunjang pencapaian sasaran program dan kegiatan pemerintah daerah dengan memperhatikan asas keadilan, kepatutan, rasionalitas dan manfaat untuk masyarakat. Hubungan bantuan sosial dengan jaminan sosial sangat berkaitan karena sangat mempengaruhi laju pertumbuhan penduduk di Indonesia. Salah satu penyebabnya peningkatan penduduk yang menyandang kecacatan yang diakibatkan dari ekonomi yang tidak memadai sehingga membuat para penyandang cacat berat menjadi bingung bagaimana bertahan hidup.

\section{Kasus/Masalah}

1) Bagaimana kondisi Indonesia sebagai negara yang mendapat bonus demografi ditengah ancaman krisis ekonomi akibat pandemic covid-19?

2) Bagaimana prosedur seleksi calon penerima bantuan sosial pada masyarakat terdampak Covid-19?

3) Bagaimana upaya pemerintah dalam menangani krisis ekonomi pada saat pandemi covid-19 ?

\section{Tinjauan Pustaka}

Dampak Krisis Ekonomi Krisis ekonomi memberikan dampak yang sangat besar bagi negara dan tentunya dari berbagai pihak, mulai dari pemerintah hingga masyarakat. Dilansir dari Detik, ketika suatu negara mengalami peristiwa tersebut, dipastikan banyak perusahaan yang melakukan pemutusan hubungan kerja (PHK) kepada karyawannya. Hal tersebut dilakukan karena perusahaan tidak memiliki cukup uang untuk memberikan gaji kepada mereka. Dengan kejadian tersebut, dipastikan juga angka pengangguran akan semakin naik. Setelahnya, angka kemiskinan juga meningkat karena orang-orang tidak memiliki pendapatan.

Pertumbuhan ekonomi yang macet Penyebab lainnya dari krisis ekonomi adalah pertumbuhan ekonomi di suatu negara tidak berkembang atau macet. Semakin buruk pertumbuhannya, maka ada kemungkinan negara tersebut masuk ke jurang krisis perekonomian. Contoh nyata karena suatu negara mengalami pertumbuhan ekonomi yang lambat adalah karena adanya virus corona seperti saat ini. Beberapa negara ada yang sudah mengalami resesi karena adanya pandemi virus corona. Bonus Demografi Menurut Kamus Besar Bahasa Indonesia, bonus di definisikan sebaga upah tambahan di luar gaji atau upah sebagai hadiah atau perangsang gaji/upah. Yang perlu digaris bawahi mengenai definisi ini adalah tambahan atau hadiah. Kalau kita mendapat tambahan atau upah atau hadiah berarti merupakan suatu keuntungan bagi kita. Bonus demografi bukan merupakan upah ataupun bukan merupakan uang.Tetapi bonus demografi diartikan sebagai keuntungan yaitu keuntungan ekonomi yang disebabkan rasio ketergantungan.

Dasar Hukum 
Peraturan Menteri Keuangan Nomor 38/PMK.02/2020 tentang Pelaksanaan Kebijakan Keuangan Negara untuk Penanganan Pandemi Corona Virus Disease 2019 (COVID19) dan/atau Menghadapi Ancaman yang Membahayakan Perekonomian Nasional, dan/atau Stabilitas Sistem Keuangan (Berita Negara Republik Indonesia Tahun 2020 Nomor 382).

\section{Bentuk Dana Bantuan Sosial dan Jaminan Sosial}

Pemerintah akan memberikan beberapa jenis bantuan sosial berupa bantuan paket sembako, Bantuan Sosial Tunai (BST) dan Bantuan Langsung Tunai (BLT). Bantuan Sosial Tunai (BST) adalah bantuan yang bersumber dari Kementrian Sosial Republik Indonesia yang akan diberikan kepada masyarakat berdasarkan pada Data Terpadu Kesejahteraan Sosial (DTKS). Sedangkan Bantuan Langsung Tunai (BLT) adalah bantuan yang berasal dari alokasi dana desa pada Anggaran Pendapatan Belanja Desa (APB Desa) yang akan diberikan oleh pemerintah kepada masyarakat yang kehilangan mata pencaharian karena pandemik virus corona atau Covid-19 selain itu juga bagi masyarakat yang tidak menerima dana Program Keluarga Harapan (PKH), Kartu Sembako, Paket Sembako, Bantuan Pangan Non Tunai (BPNT) hingga Kartu Prakerja. Masyarakat calon penerima BST maupun BLT akan menerima bantuan uang tunai sebesar Rp 600.000,00 per kepala keluarga setiap bulannya selama tiga bulan.

Gerakan Masyarakat Sehat Germas adalah sebuah Gerakan yang bertujuan untuk memasyarakatkan budaya hidup sehat serta meningkatkan kebiasaan dan perilaku masyarakat yang kurang seahat.Aksi GERMAS ini juga diikuti oleh lansia untuk lenih menerapkan perilaku hidup sehat . Lansia merupakan suatu kelompok penduduk yang cukup rentan dan terdampak dalam masalah kesehatan danpsikologis di era pandemi COVID 19 (new normal). Salah satu usaha dari pemerintah dalam menjaga lansiaagar tidak terpapar wabah ini adalah dengan promosi kesehatan di Posyandu Lansia. Tujuan dari kegiatan adalah penyuluhan PHBS dan GESMAS (Gerakan Masyarakat Hidup Sehat) yang merupakan bagian dari promosi kesehatan dalam bidang kesehatan lingkungan dalam mendukung pemutusan rantai penyebaran COVID 19 dan siap menghadapi masa new normal.

\section{Pembahasan}

Coronavirus adalah kumpulan virus yang bisa menginfeksi sistem pernapasan. Pada banyak kasus, virus ini hanya menyebabkan infeksi pernapasan ringan, seperti flu. Namun, virus ini juga bisa menyebabkan infeksi pernapasan berat, seperti infeksi paru-paru (pneumonia). Virus ini menular melalui percikan dahak (droplet) dari saluran pernapasan, misalnya ketika berada di ruang tertutup yang ramai dengan sirkulasi udara yang kurang baik atau kontak langsung dengan droplet. Tingkat kematian (case fatality rate) akibat COVID-19 adalah sekitar 2,9\%. Jika dilihat dari persentase angka kematian yang di bagi menurut golongan usia, maka kelompok usia 46-59 tahun memiliki persentase angka kematian yang lebih tinggi dibandingkan golongan usia lainnya. Gejala Virus Corona (COVID-19) Secara umum, ada 3 gejala umum yang bisa menandakan seseorang terinfeksi virus Corona, yaitu: Demam, (suhu tubuh di atas 38 derajat Celsius), Batuk kering, Sesak napas. Ada beberapa gejala lain yang juga bisa muncul pada 
infeksi virus Corona meskipun lebih jarang, yaitu: Diare, Sakit kepala, Konjungtivitis, Hilangnya kemampuan mengecap rasa, Hilangnya kemampuan untuk mencium bau (anosmia).

Upaya Pemerintah dalam Menangani Krisis Ekonomi Saat Pandemi COVID-19 Sebagai sebuah negara yang memiliki bonus demografi di era ini, ditambah dengan posisi indonesia sebagai negara anggota G20 yang mewakili wilayah Asia Tenggara, serta telah dimasukannya isu bonus demografi ke dalam Rencana Pembangunan Jangka Menengah Nasional (RPJMN) 2015-2019. Termasuk menjabarkan kerangka pelaksanaannya. Hal ini menunjukkan bahwa fenomena bonus demografi telah disadari dan mendapatkan perhatian dari pemerintah. Salah satu upaya pemerintah untuk menghadapi era bonus demografi ini melalui pemerataan pendidikan dasar bagi seluruh penduduk Indonesia dengan memberikan beasiswa dari Lembaga Pengelola Dana Pendidikan (LPDP) sebesar 1,3 Triliun. Pemerataan akses pendidikan dasar terutama bagi penduduk yang ada di pelosok dan kurang mampu secara tidak langsung akan meningkatkan kualitas sumber daya manusia Indonesia. Berbagai kebijakan perlu dibuat dan dilakukan oleh Indonesia guna dapat mampu menekan angka stabilitas ekonomi di Indonesia. Pada saat ini dimana Indonesia sedang di hadapkan oleh krisis ekonomi akibat lambatnya laju pertumbuhan ekonomi serta banyaknya masyarakat yang bekerja terpaksa dirumah akibat banyaknya lapangan pekerjaan yang tutup sementara akibat masalah pandemi ini maka pemerintah mengeluarkan berbagai kebijakan bersamaan dengan kebijakan yang dikeluarkan oleh pemerintah daerah khususnya daerah yang saat ini menjalankan kebijakan PSBB guna menanggulangi penyebaran virus tersebut. Pemerintah pusat mengeluarkan beberapa kebijakan ekonomi guna mengatasi masalah akibat Pandemi COVID-19.

Program Germas Penyuluhan Perilaku Hidup Sehat dan Bersih (PHBS)kepada Lanjut Usia (LANSIA) Menghadapi Masa Pandemi Covid 19 dan NewNormal dengan Metode 3M. Banyak sekali program Germas yang sudah dilakukan pemerintah dalam menghadapi masa pandemic covid seperti sekarang ini.karna lansia merupakan umur yang rentan sekali terkena covid19,jadi harus ada pemahaman khusus buat meraka.penyuluhan ini sangat bermanfaat apalagi jika merka ada komplukasi dari penyakit dimasa Lansia Mereka.

Depkes RI (2011), menyatakan bahwa membasuh tangan dengan air yang bersih dapat memangkas kuman diare. Penyakit diare seringkali diasosiasikan dengan keadaan air, namun secara akurat sebenarnya harus diperhatikan juga penanganan kotoran manusia seperti tinja dan air kencing, karena kuman-kuman penyakit penyebab diare berasal dari koto

ran-kotoran ini.

\section{Kesimpulan}

Dengan demikian sebagai sebuah negara yang mendapatkan bonus demografi saat ini, Negara Indonesia harus mampu menanfaatkan posisi tersebut walaupun saat ini Indonesia sedang berada titengah ancaman krisis ekonomi akibat wabah virus corona dimana di saat ini, posisi pertumbuhan ekonomi Indonesia sedang mengalami perlambatan serta berbagai persoalan akibat wabah virus corona seperti halnya banyaknya pemutusan hubungan kerja, serta perlambatan laju investasi. Sebagai sebuah negara yang memiliki bonus demografi di era ini, Indonesia harus mampu menjaga pertumbuhan ekonominya guna dapat meningkatkan pembangunan negara. 
Lansia merupakan suatu kelompok penduduk yang cukup rentan dan terdampak dalam masalah kesehatan danpsikologis di era pandemi COVID 19 (new normal). Salah satu usaha dari pemerintah dalam menjaga lansia agar tidak terpapar wabah ini adalah dengan promosi kesehatan di Posyandu Lansia. Beberapa pokok penting dari penyaluran bantuan dana jaminan sosial bagi para penyandang cacat berat. Rincian dari kesimpulan ini merupakan isi terpenting dalam prosedur bantuan yang harus dilakukan komponen dan atau petugas sosial.

Cuci tangan pakai sabun merupakan hal yang sangat penting untuk mencegah beberapa penyakit menular yaitu antara lain covid-19 dan diare. Diare dapat berasal dari kotoran-kotoran dan kuman-kuman seperti dari air kencing, tinja, dan lain-lain. Kuman ini akan membuat manusia sakit apabila ada yang masuk dalam mulut kita, maka dari itu mencuci tangan menjadi hal yang sangat penting untuk mencegah penyakit yang salah satunya adalah kejadian covid-19 dan diare.

\section{DAFTAR PUSTAKA}

Dadu, Fridolin Dapa, and Muhammad Ali Sodik. "Penyaluran Bantuan Dana Jaminan Sosial bagi Masyarakat yang Terdampak Covid-19." (2021).

Dadu, F. D., \& Sodik, M. A. (2021). Penyaluran Bantuan Dana Jaminan Sosial bagi Masyarakat yang Terdampak Covid-19.

DADU, Fridolin Dapa; SODIK, Muhammad Ali. Penyaluran Bantuan Dana Jaminan Sosial bagi Masyarakat yang Terdampak Covid-19. 2021.

Fidhiniyah, Nur Rochmah, and Muhammad Ali Sodik. "Krisis Ekonomi Di Indonesia Disebabkan Oleh Pandemi Covid-19."

Fidhiniyah, N. R., \& Sodik, M. A. Krisis Ekonomi Di Indonesia Disebabkan Oleh Pandemi Covid-19.

FIDHINIYAH, Nur Rochmah; SODIK, Muhammad Ali. Krisis Ekonomi Di Indonesia Disebabkan Oleh Pandemi Covid-19.

Fidhiniyah, Nur Rochmah, and Muhammad Ali Sodik. "Krisis Ekonomi Di Indonesia Disebabkan Oleh Pandemi Covid-19."

FIDHINIYAH, Nur Rochmah; SODIK, Muhammad Ali. Krisis Ekonomi Di Indonesia Disebabkan Oleh Pandemi Covid-19.

Fidhiniyah, N. R., \& Sodik, M. A. Krisis Ekonomi Di Indonesia Disebabkan Oleh Pandemi Covid-19.

M'jai, Alfrida Brigitha, and Muhammad Ali Sodik. "Germaspenyuluhanperilakuhidupsehat Dan Bersih (PHBS) Kepadalanjutusia (LANSIA) Menghadapi Masa Pandemicovid 19 Dan New Normal Denganmetode 3M." (2021).

M'jai, A. B., \& Sodik, M. A. (2021). Germaspenyuluhanperilakuhidupsehat Dan Bersih (PHBS) Kepadalanjutusia (LANSIA) Menghadapi Masa Pandemicovid 19 Dan New Normal Denganmetode 3M. 